\title{
Real Estate-Backed Securities in China: the Unresolved Issue of True Sale and Bankruptcy-Remoteness
}

\author{
Shiyi Huang* \\ 31st Floor, Building A of East District, Jianwai SOHO, NO.39, Middle Road of East Third Ring, Chaoyang \\ District, Beijing, China, 100022 \\ huangshiyi@zhongyinlawyer.com
}

Keywords: Asset-Backed Securities, Corporate Financing, Real Estate Investment and Finance, Future Receivables, True Sale, Bankruptcy-Remoteness

\begin{abstract}
Real Estate-Backed Securities('REBS') are widely acknowledged as a cost-effective way for enterprises to raise funds directly from market investors through securitising real estate receivables, while the current legal environment in China makes true sale and bankruptcy-remoteness, two characteristics that separate REBS from loans, impossible to be achieved. This article offers an engaging introduction to REBS by situating it in a wider commercial context, provides a clear description of the typical procedures used in current REBS practice, conducts an in-depth analysis of the causes of the said two problems and ultimately puts forward to two legally modified multiple-tier structures and one final solution which may hopefully be used to solve the said problems.
\end{abstract}

\section{Introduction}

In 2005, the China Banking Regulatory Commission passed the first legislation related to Asset-Backed Securities ('ABS') called "Measures for the Supervision and Administration of Pilot Credit-Based Asset Securitisation of Financial Institutions", with the purpose of providing financial institutions with an effective way to raise funds. However, the regulation which allows non-financial corporations to issue securities based on their cash flow generating assets was not released until 2014, when the China Securities Regulatory Commission ('CSRC') published "Administrative Provisions on the Asset Securitisation Business of Securities Companies and Subsidiaries of Fund Management Companies” ('ABS Provision'). In this document, issuing securities based on the right to obtain proceeds from immovable properties owned by originators was officially permitted, allowing Real Estate-backed Securities to be created in China.

REBS specifically refers to the process of converting future receivables from real property into securities to be offered and traded among qualified investors and is viewed as a significantly important way for corporations which either own real estate or enjoy franchise rights over public-owned real estate to raise capital at a relatively low cost and risk levels.[1] The so-called “franchise rights” are a common feature in Public-to-Private Partnership Projects ('PPP'), in which the private companies will sign a contract with the local government, investing money in building municipal public infrastructures such as highways, bridges, tunnels, and ferries, and have their costs and profits covered by gaining franchise rights granted by the local government. Through exercising the said right, companies can operate these projects and charge money from the users.

According to statistics, the rental yield for residences in China ranged from 4.5-5.1\% in 2016, and that for commercial estates such as shops and office buildings was between 6.3-7.3\%.[2] Similarly, the average annual return on PPP projects was 7.13\% in 2016.[3] This means that the capital invested in those projects may be taken up for at least 14 years before it returns from the cash flow that the projects generate. Instead of waiting for such a long time, one can turn to the use of REBS instead. However, notwithstanding the unique financial benefits brought by REBS, legal problems related to true sale and bankruptcy-remoteness are still unsolved under its typical 
structures.

\section{Typical Structures}

In China, the operation and management of securities are separated from those of banking, trusteeship, and insurance, which means that the CSRC is not entitled to regulate businesses related to the abovementioned three fields. As a result, unlike the ABS in the U.S. which normally adopts a trust structure for the securitisation process, the CSRC has created its own vehicle called "Asset-Backed Special Schemes" ('the Special Scheme'), which is expected to have a function similar to trusts and is generally set up by securities companies as an independent entity to manage, utilise and dispose of the underlying assets.[4] The steps of issuing ABS in the primary market are as follows:

Step 1: Corporations which are seeking to finance ('the originator') will choose suitable underlying assets, which need to be in compliance with Chinese laws and regulations, have clear ownership and be able to generate independent and predictable cash flow. The assets listed in "The Negative List of the Underlying Assets of Asset-backed Securities" published by the Asset Management Association of China in 2014, such as real estate remaining to be developed, should be excluded.

Step 2: The originator signs a sales contract with a securities company ('the manager') to sell the underlying assets to the Special Scheme. The following contents will normally be included in the said contract: the agreement on the securities company to be the manager and to set up the Special Scheme, the duration and termination conditions of the Special Scheme, the scope of the underlying assets, the conditions and methods for the manager to make the payment, etc.

Step 3: The manager signs a service contract with a service provider which is usually the originator itself, entitling the service provider to provide services for underlying assets which have been transferred to the Special Scheme, including maintaining their functions, charging usage fees from the users, settling accounts and transferring the earnings to the account of the Special Scheme, etc.

Step 4: The manager signs a contract with a commercial bank ('the fund depositary institution'). The assets under the Special Scheme, which are constituted by the payment made by the original investors to purchase the corresponding ABS and the cash flow generated by the underlying assets, will be placed under the custody of the fund depositary institution.

Step 5: The qualified investors ('the original investors') will sign a subscription agreement with the manager, making the payment to the Special Scheme and thereby becoming holders of the ABS.

Step 6: Once the size of the asset-backed securities issued reaches the minimum issuance size specified in the statements on the Special Scheme, the establishment of the Special Scheme becomes complete. The payment received by the Special Scheme will be transferred to the originator as consideration for the underlying assets. Correspondingly, the cash flow generated by the underlying assets will be collected by the service provider, and then be transferred to the Special Scheme. Every time the accumulation of cash meets the amount stated in the subscription agreement, the manager will distribute it to the investors accordingly.

\section{Problems Faced by True Sale}

Under the context of REBS, a true sale opinion is given to guarantee that the transferred assets have been truly sold on a permanent basis instead of being used as a tool to secure financing.[5] The legal problems currently preventing a transaction from being defined as a true sale in China could be concluded as follows:

Lack of a Transferable Right. One indispensable prerequisite of a sale is that the subject matter is transferable, which means that the transferor either enjoys real rights or creditors' rights over it. Legally speaking, the real rights should be transferred through registration or delivery, and the creditors' rights should be transferred through notifying the obligor. However, gaining future receivables from an immovable is not a real right prescribed by Real Rights Law of the PRC, 
despite the truth that owners and some other real right holders did be entitled to benefit from an immovable.[6] Similarly, it cannot be counted as a creditors' right either, since Article 118 of General Rules of the Civil Law defines creditors' rights as the rights possessed by a right holder to require a specific obligor to perform or not to perform certain obligations, while the obligor cannot be specified under REBS since the debt has not occurred.

In the U.S., the right of gaining future receivables from real property can be viewed as "rights to payment from a commodity's future trading account" and therefore be included in the category of "general intangibles", one that is stipulated in Article 9 of Uniform Commercial Code 2010.[7] The said right is allowed to be used as collateral and to be transferred during the procedure of enforcement. In China, however, even though pledges of receivables from real property is legally acknowledged, it does not mean that the right of gaining future receivables can necessarily be transferred.[8] In fact, in one guiding case published by the Supreme People's Court of PRC, Fujian Haixia Bank Co. Ltd. v. Changle Yaxin Sewage Treatment Co. Ltd. and Fuzhou Municipal Engineering Co. Ltd, the court held that the right of gaining receivables based on franchise is not suitable for sale, and thus if the pledgee claims to enforce its right through selling the object of pledge through auction , the court will order the pledger to make the payment through the money received by the receivables' account instead.[9] This shows that the transferability of the right of gaining future receivables is still questionable.

Lack of a Qualified Transferee. To transfer the underlying assets to the Special Scheme, the originator needs to sign a sale contract with the securities company which manages the Special Scheme. This is because without being registered as a legal person or other organisation, the Special Scheme itself does not have the capacity for civil rights and civil conduct, which means that it is not qualified for being a party to contracts. Therefore, serving as the manager, the securities company needs to be a representative to conduct legal acts on the Special Scheme's behalf.

However, unlike trust companies which can claim under Trust Law of the PRC that "the trust property is independent of the trustor, the trustee and the beneficiary within the duration of the trust”, securities companies are not entitled to such a privilege. Even though it has been stipulated that client securities shall be separated from its own assets in accordance with Securities Law of the PRC, a securities company still cannot separate its own assets from that of a Special Scheme. It is mainly because said assets controlled by the securities company either belong to its clients or itself according to the regulation mentioned above, while the Special Scheme cannot be defined as a client since it is legally incapable of signing a securities contract. Consequently, there is no legal basis for the underlying assets transferred to the securities company to be deemed as the assets owned by the Special Scheme, which makes the securities company an unqualified transferee.

Lack of Applicable Criteria. Article 3 of the ABS Provision provides that underlying assets, including property rights and assets, shall have authentic transaction bases and fair transaction considerations, yet there are no clear criteria in place to define if a transaction successfully meets these two requirements. If we draw knowledge from the legal practice in the U.S., we will see that courts here normally view the intent of the parties and the economic consequences of the transaction as the two main factors which define a true sale. On the one hand, the parties need to clearly and unambiguously reveal their intention in the sale contract, and the intention needs to closely resemble a sale instead of a loan.[10] On the other hand, the risk of loss initially borne by the transferor should be passed to the transferee, together with the right of reaping the benefits of ownership, from which we can deduce that the transferee should not have right to recourse against the transferor under the context of a true sale.[11]

In China, however, the sales of underlying assets are commonly coupled with the originator's obligations of maintaining their values and reaping the excess return, which makes the ABS process more similar to a secured loan.[12] For instance, in 2015, Guangzhou Rapid Transit Construction Co. Ltd issued an ABS based on its right to charge entrance fees from the users of Guangzhou Airport Expressway within a certain period of time in the future, with a promise of making up a deficiency when the receivables fail to meet the expected requirement provided in the sale contract, and a right of repurchasing the underlying assets before the due date of distribution. Another 
example is that in a Special Scheme established by Guangzhou Chime-Long Group Co., Ltd. in 2014, in which the underlying assets was the future entrance fee of Chime-Long Park, and the manager was entitled to require the originator to cover the gap between the expected receivables and the real ones in the name of investors, and if the originator failed to do so, the guarantor would be required to assume guarantee liability.[13]

To conclude, even though there is currently no lawsuit relevant to the "true sale" conception recognized in Chinese judicial practice, it is foreseeable that the abstract and ambiguous criteria toward true sale will ultimately lead to legal conflicts, especially considering that many REBS cases are already more akin to loans instead of true sales.

\section{Problems Faced by Bankruptcy-Remoteness}

Serving as a special purpose entity, the Special Scheme is established to isolate the underlying assets from insolvency or bankruptcy of any party, and it works by transferring the assets from the originator to the Special Scheme. Therefore, the failure of accomplishing true sale ultimately makes bankruptcy-remoteness impossible.[14] Besides, bankruptcy-remoteness for REBS is still far-fetched under current Chinese legislation due to the following two reasons:

Conflicts with Bankruptcy Law. Considering that the underlying assets will be transferred and ultimately be registered under the name of the manager, it is of foremost importance to isolate the said assets from the manager's bankrupt property. According to Article 30 of the Bankruptcy Law of the PRC, all property that belongs to the debtor at the time when the application for bankruptcy is accepted is bankruptcy property. In order to achieve the separation, ABS Provision provides that the assets under a Special Scheme shall be independent of the proprietary assets of the managers and shall not belong to the assets for liquidation.

However, unlike Trust Law which can successfully separate the trust property from a trustee's liquidation property since the legal position of Trust Law equals that of Bankruptcy Law, ABS Provision cannot serve the same purpose. It is mainly because ABS Provision belongs to normative legal documents which have lower legal effectiveness than legislation and therefore are not entitled to enlarge or narrow the scope of "bankruptcy property" which has been defined in Bankruptcy Law. Correspondingly, the effort made by ABS Provisions to achieve bankruptcy-remoteness during ABS process is in vain since the same regulation has not been adopted by Bankruptcy Law or any legislation at the same level.

Conflicts with Accounting Standards. To avoid being relegated to bankruptcy property of the originator, the cash flow generating assets should be specially marked in the originator's financial statements after it is transferred to the Special Scheme, showing that the originator is not holding the right of gaining future receivables anymore. Through doing this, the potential creditors will not be misled by the information shown on the financial statements and will not wrongly trust the originator with its capability of paying the debts back. However, this goal is currently impractical from an accounting aspect.

When it comes to dealing with the assets of which the right of gaining receivables have been transferred, the only relevant accounting standards are "Accounting Standards for Business Enterprises No. 23 - Transfers of Financial Assets”, which allow an enterprise to derecognize a financial asset when it transfers its right to receive the cash flow from the said financial asset to another party, together with all the attached risks and rewards. However, it should be noted that financial assets here refer to intangible assets that generate receivables because of a contractual claim, such as bank deposits, bonds, and stocks, and real estate are not included in this context, which means that no matter if the said right is transferred or not, it does not affect the value of the real estates on financial statements, creating the same rights appearance for creditors of the originator. This makes the bankruptcy-remoteness of REBS legally unjustified.

\section{Suggested Solutions}

Adopting a "Trust Plus the Special Scheme” Structure. In order to achieve the goal of true sale 
and bankruptcy-remoteness, a trust needs to be established as a first-tier SPE, followed by the Special Scheme as a second-tier. The transaction could be designed as follows:

Firstly, being the trustor, the originator will initially entrust a trust company with the ownership of the profit-generating real-estate in order to establish a self-benefit trust, with itself being prescribed as the beneficiary of the trust and being named as the holder of the real estate when the trust is terminated.[15] Meanwhile, being the trustee, the trust company will be given the responsibility of managing the real estate with the purpose of guaranteeing the stable future cash flow that it can generate, and the beneficiary right under this context equals the right of gaining future receivables generated by the real estates. Since Article 48 of the Trust Law permits the transaction of the beneficiary right, a transferable right of gaining receivables generated by the real estates is thereby created.

Secondly, the originator will find a securities company to establish a Special Scheme, and then sell the beneficial right of the trust to the said Scheme, in which case the true sale can technically be achieved.[16] And since this process successfully makes the trust not a self-benefit one anymore, even though the originator is dissolved, canceled or declared, the trust will continue to exist according to Article 15 of the Trust Law and the real estates will not be deemed as liquidation property, which makes bankruptcy-remoteness from the originator an achievable goal. After the Special Scheme sells the securities to the investors, the originator will accomplish the fund-raising goal while still retaining the right of having the real estate back after the trust terminates.

However, there are still some flaws related to this structure. Firstly, the prerequisite for the establishment of a trust is that the right over the real estate has to be transferable so that it can be transferred from the originator to the trust, which is indeed the case for those originators who own the real estate but is not the case for those who simply enjoy franchise rights over the real estate in PPP projects.[17] Consequently, this structure cannot serve for the purposes of true sale and bankruptcy-remoteness for the latter. Additionally, although a trust is involved in this case, the beneficial right will ultimately be transferred to the manager of the Special Scheme which is a securities company, thus when the said company goes bankrupt, it is still not guaranteed that the beneficial right can be prevented from being relegated to its liquidation property. As a result, bankruptcy-remoteness under this structure is not one hundred percent guaranteed.

Adopting a "Private Funds Plus the Special Scheme" Structure. Firstly, a special purpose company ('SPC') will be established by the originator and the real estate will be transferred to the said SPC.[18] It should be noted that this process will not necessarily happen since the necessity of using an SPC mainly depends on whether the originator has any other assets, debts, existing subsidiaries or not. If their assets contain nothing but the cash flow generating assets which are to be used for REBS purposes and they are currently debt-free, then an extra SPC does not need to be established. This process will effectively solve the problem of having a "lack of transferable right" faced by originators who only enjoy franchise rights of the real estates. This is because a project company is required to be established before a PPP project starts, in which the originator is the main shareholder and will make the investment, build and operate the infrastructures through the project company, therefore, in this case, the project company itself can be used as a readily available SPC.[19] Since the franchise rights enjoyed by the project company are not transferable, the originator can retain this right in the project company without affecting the process of REBS under this structure.

Secondly, a private securities fund which takes the legal form of a limited partnership will be created. In the meantime, the SPC or project company will issue "preferred shares" to the originator through tailoring the rules of drawing dividends and exercising the voting rights in articles of association, which allows the originator to solely enjoy all the profits generated by the company. Then the preferred shares will be sold by the originator to the private fund managed by a privately offered fund manager who is also the general partner of the fund.[20] This process is crucially important for bankruptcy-remoteness since as long as all the shareholders agree in the company's articles of association that the preference shareholders are entitled to draw all the dividends from the SPC or project company, the preference shareholders' right almost equals the right of gaining 
future receivables. More importantly, if the said right is transferred to a third party, it will not be affected by the originator anymore, even under the condition that the originator goes bankrupt and the other shares that it holds over the SPC or project company are consequently viewed as "liquidation property".

Thirdly, a Special Scheme will be established and become the limited partner of the private fund through subscribing the fund. This process makes it possible for the Special Scheme to indirectly acquire the future receivables generated by the real estate through gaining distribution of cash dividends based on the "preferred shares" issued by the SPC or project company holding the real estate, and to avoid being affected by the possible risks occurred in the corporate operation. After the Special Scheme sells the REBS to the investors, the originator will achieve the goal of fundraising while remaining in control of the real estates.

Compared with "Trust plus the Special Scheme” structure, this one successfully solves the true sale and bankruptcy problems faced by originators whose cash-generating assets are not transferable. Also, since Private Funds and the Special Scheme are commonly regulated by the China Securities Regulatory Commission, it can effectively avoid the regulatory conflict which may possibly be caused by the involvement of trusts which are regulated by the China Banking Regulatory Commission. However, this structure still cannot isolate the underlying assets from the manager of the Special Scheme and cannot control the risks caused by the bankruptcy of the managers.

Publishing a Special Law. Since the solutions established on the basis of the original legal system have comparatively less legislative cost while tailoring the current legal system to suit the needs of the practice costs much more, the above-mentioned two structures should be given priorities in terms of solving this issue.

Nevertheless, there are still unavoidable drawbacks faced by the said structures. Firstly, multiple-tier transactions require higher financial costs in establishing and maintaining the special purposes entities, in hiring trust companies or privately offered fund managers, and especially in paying taxes arisen in every single transaction, such as income tax and added-value tax, which may make REBS, an originally low-cost financing method ultimately unaffordable. Secondly, no matter how complicated the transaction structure is designed to be, it is still an unsolvable problem for the Special Scheme to be isolated from the bankruptcy of the manager. Finally, no matter how plausible the proposed structures appear, judges are still the final decision maker in terms of true sale and bankruptcy-remoteness, so it is still of great importance to have clear regulations enacted regarding REBS in China.

Considering that there is a great amount of legislation, such as Real Rights Law, Enterprise Bankruptcy Law, and Securities Law that needs to be amended to suit the needs of REBS, instead of amending the current legislation which may be time-consuming and costly, the author's suggestion is to draft a law specifically addressing REBS, in which the right of gaining future receivables should be viewed as "future claims" and be allowed to transfer, the public summons of the transaction of such future claims should also be adopted to warn the potential buyers of the encumbrances on the corresponding real estates, the assets under a Special Scheme should be separated from that of the originators, managers, and investors and a series of criteria should be created to define a true sale. Being recognised as a special and new provision enacted by the same body that issued the above-mentioned laws, the newly drafted law will not only establish clear rules for the function of REBS but will also prevent the conflicting rules stated in other laws from being adopted.[21]

\section{Conclusions}

ABS provides corporations equipped with cash-flow generating assets a new financing method, and unlike loans, the underlying assets of ABS need to be truly sold to the SPV which will issue securities to the investors, for the purpose of creating a firewall between the bankruptcy of the originators and their assets. Through doing this, investors will value the underlying assets more and the scales and fame of the originator less, which makes it possible for small and medium enterprises to be treated equally in the process of financing.[22] However, as one type of ABS, REBS fails to 
achieve the "true sale" and "bankruptcy-remoteness" goals due to the non-transferable nature of its underlying assets (the right of gaining future receivables from the real estates), the independent merit of the Special Scheme and the lack of clear criteria for defining "true sale". Also, since the current ABS regulation is conflicted with the Bankruptcy Law and the Accounting Standards, "bankruptcy-remoteness" is a far-fetched goal in the practice.

To solve the above-mentioned problems, two legally modified structures, which involve trusts and private funds in the transaction process respectively, are suggested to be used. The said structures can turn non-transferable underlying assets into beneficiary rights and preferred shares respectively, which are both transferable, thereby making a "true sale" possible. The independent status of trusts protected by Trust Law and the separate status of the shareholders (which means that one shareholder will not be affected by the bankruptcy of another shareholder) protected by Company Law also make "bankruptcy-remoteness" an achievable goal. Nevertheless, in order to reduce transaction costs, drafting and publishing a new law specifically addressing the operation of REBS can ultimately be considered as a final solution.

* Shiyi Huang, Trainee Solicitor, Zhong Yin Law Firm (Beijing). The author assisted several institutions including Hulun Buir Housing Provident Fund Management Centre and Hulun Buir City Investment Group to issue Asset-Backed Securities in 2016. She was then honored with an invitation to the Fourth Qingjin Commercial Law Forum (a workshop focusing on Asset-Backed Securities) held by the Law Faculty of Tsinghua University on 1st July, 2017. She gratefully acknowledges the assistance of Ju Li, Steven Hsu, Ricky D. Hepburn and Jared H. LaLiberte in the preparation of this article.

\section{References}

[1] Thomas E. Plank. Sense and Sensibility in Securitization: A Prudent Legal Structure and A Fanciful Critique[J]. Cardozo Law Review, 2008, 11: 615-618.

[2] Information on http://www.yunfangdata.com/transactionData.html?type=3

[3] Information on http://www.sohu.com/a/115993025_475876

[4] Lingyan Hsu. Comparative Study on Legal System of Financial Supervision: Global Financial Legal System Reform and China’s Choice[M]. Beijing: Law Press China, 2016, 10: 130-136. (In Chinese)

[5] Kenneth C. Kettering. True Sale of Receivables: A Purposive Analysis[J]. American Bankruptcy Institute Law Review, Winter 2008: 526-532.

[6] National People's Congress. Real Rights Law of the PRC.[M]. Beijing: China Legal Publishing House, May 1, 2016, Article 5.

[7] Lawrence R. Ahern III. Secured Transactions Under Article 9 of the Uniform Commercial Code[J]. The Law of Debtors and Creditors, 2017, 6: 211-212.

[8] Supreme People's Court of the PRC. Judicial Interpretation of the Supreme People's Court on Certain Issues Regarding the Application of the Security Law of the PRC.[M]. Beijing: Law Press China, 2003, 1: Article 97.

[9] Supreme People's Court. Guiding Cases Released by the Supreme People's Court: the 1st to 16th Batches[M]. Beijing: People's Court Press, 2017, 6: 218-223.

[10] Michael Gaddis. When is A Dog Really A Duck: The True-Sale Problem in Securities Law[J]. Texas Law Review, 2008, 12: 489-490.

[11] M. John Sterba, Jr., James E. Clark and Teresa W. Harmon. Legal Opinion Letters[M]. New 
York: Aspen Publishers, 2017: 66-68.

[12] James Gadsden. When is The Factoring of Accounts A True Sale?[J]. American Bankruptcy Institute Journal, 2015, 12: 38-39.

[13] Information on http://abs.seid.com.cn/plxx/s_zqjys/2016/01/194563.shtml

[14] Matthew B. Farber. Securitized Lending, Special Purpose Vehicles, and Substantive Consolidation[J]. Lincoln Law Review, 2011-2012: 44-45.

[15] Lianhui Zhao. Trust Law in China[M]. Beijing: China Legal Publishing House, 2015, 8: 188-191. (In Chinese)

[16] Lingyun Gao. An Analysis of the Legitimacy of the Trust Based On Future Receivables[J]. Law Science, 2015( Vol.7 ) : 149-151. (In Chinese)

[17] John A. Pearce II, Ilya A. Lipin. Spcial Purpose Vehicles in Bankruptcy Litigation[J]. Hofstra Law Review, Fall 2011: 183-184.

[18] Baxter Dunaway. Law of Distressed Real Estate[M]. New York: Clark Boardman Callaghan, 2017: §56:28.

[19] Ministry of Finance of the PRC., Circular on Issuing the Operational Guidance on the Modes of Cooperation by Governments and Social Capital[M]. China Legal Publishing House, 2014, 11: Article 23.

[20] Zhiwei Gu. A Practical Guideline for Private Equity Investment Fund[M], Beijing: Law Press China, 2015, 8: 149-152. (In Chinese)

[21] National People's Congress. Legislative Law of the PRC[M]. Beijing: Law Press China, 2015, 3: Article 92.

[22] Jiaqing Feng, Typical Cases and Practical Operation of Real Estate Investment and Financing[M]. Beijing: Law Press China, 2014, 10: 376-379. (In Chinese) 